\title{
Mechanisms of tolerance to water deficit and physiological responses to rehydration in cowpea ${ }^{1}$
}

\author{
Mecanismos de tolerância ao déficit hídrico e respostas fisiológicas a reidratação em \\ feijão-caupi
}

\author{
Johny de Souza Silva ${ }^{2 *}$ Rafael Santiago da Costa ${ }^{2}$, Francisco Linco de Souza Tomaz ${ }^{2}$, Antônio Erivando \\ Bezerra $^{3}$ and Rosilene Oliveira Mesquita ${ }^{2}$
}

\begin{abstract}
The cowpea bean is one of the main legumes grown in the Northeast region, with a purpose directed to the production of dried grains or green pods. However, this region suffers from climatic variations, with drought being the main abiotic stress factor. Therefore, the objective was to evaluate the physiological, morphological and pod production characteristics of traditional cowpea varieties in terms of drought tolerance and rehydration in the Brazilian semiarid region. The varieties were: Pingo de Ouro 1,2 (PO), Sempre Verde (SV) and Feijão de Moita (FM). The experimental design used was entirely randomized, in a 3 x 2 factorial scheme ( 3 genotypes $\mathrm{x} 2$ soil water conditions) with 5 replicates for each treatment, totaling 30 experimental units. Growth variables, carbon metabolism, and pod production were evaluated. The results suggest that the water stress negatively affected the cowpea genotypes, especially those that had negative effects on the morphological level and pod production. In these aspects, the genotype FM was the most sensitive to the severe water stress. However, Creole genotypes showed characteristics physiology similar to the standard tolerance genotype, the PO. Also, all genotypes recovered after rehydration. In terms of pod production and characteristics, the genotype PO, in general, presented better responses under stress conditions.
\end{abstract}

Key words: Semi-arid. Vigna unguiculata (L). Walp.. Ecophysiology.

RESUMO - O feijão-caupi é uma das principais leguminosas cultivadas na região Nordeste, com finalidade direcionada para a produção de grãos secos ou vagens verdes. No entanto, essa região sofre com variações climáticas, sendo a seca o principal fator de estresse abiótico. Portanto, objetivou-se avaliar as características fisiológicas, morfológicas e de produção de vagens em variedades tradicionais de feijão-caupi quanto à tolerância à seca e reidratação no semiárido brasileiro. As variedades foram: Pingo de Ouro 1,2 (PO), Sempre Verde (SV) e Feijão de Moita (FM). O delineamento experimental utilizado foi o inteiramente casualizado, em esquema fatorial 3 × 2 (3 genótipos x 2 condições hídricas do solo) com 5 repetições para cada tratamento, totalizando 30 unidades experimentais. Foram avaliadas variáveis de crescimento, metabolismo do carbono e produção de vagens. Os resultados sugerem que o estresse hídrico severo afetou negativamente todos os genótipos de feijão-caupi, sendo nesses aspectos o genótipo FM o mais sensível ao déficit hídrico severo, pois, demonstrou efeitos negativos em nível morfológico e produção de vagens mais pronunciadas. No entanto, os genótipos crioulos apresentaram características físiológicas semelhantes ao genótipo padrão de tolerância, o PO. Além disso, todos os genótipos apresentaram recuperação após a reidratação. Em termos de produção e características de vagens o genótipo PO, em geral, apresentou melhores respostas sob condição estresse.

Palavras-chave: Semiárido. Vigna unguiculata (L). Walp.. Ecofisiologia.

DOI: $10.5935 / 1806-6690.20210034$

Editor-in-Article: Eng. Agrônoma, dra. Ana Kelly Silva - kelly.firmino@ufc.br

*Author for correspondence

Received for publication 24/02/2020; approved on 14/10/2020

'Parte da Dissertação do primeiro autor, apresentado ao Curso de Pós-Graduação em Agronomia/Fitotecnia - Universidade Federal do Ceará/UFC

${ }^{2}$ Departamento de Fitotecnia, Centro de Ciências Agrárias/CCA, Universidade Federal do Ceará/UFC, Campus do Pici, Fortaleza-CE, Brasil, johny.ufca@gmail.com (ORCID ID 0000-0001-5673-7114), rafaelsantiagodacosta@yahoo.com.br (ORCID ID 0000-0002-3158-2117), lincotomaz@gmail.com (ORCID ID 0000-0002-8696-8914), rosilenemesquita@gmail.com (ORCID ID 0000-0002-6310-8196)

'Departamento de Engenharia Agrícola da Universidade Federal de Campina Grande/UFCG, Campus Campina Grande, Campina Grande-PB, Brasil, aerivando86@gmail.com (ORCID ID 0000-0003-4097-8014) 


\section{INTRODUCTION}

The use of irrigation in agriculture has become more and more frequent as it promotes gains in productivity. However, in arid and semi-arid regions, where evapotranspiration rates are higher than precipitation, water deficiency is the main abiotic factor limiting plant growth and increased production, still the major bottleneck in agricultural production in these regions (CARDOSO; MELO; RIBEIRO, 2018). Therefore, the drought caused by water deficit, becomes the main abiotic limiting factor for plant growth and production, occurring mainly in the aforementioned regions (CHEN et al., 2018).

The waterdeficitcan be defined as a water deficiency, which is observed from a reduction in the availability of water in the soil, or through the morphological, physiological, and biochemical responses of plants to lack of water (IHUOMA; MADRAMOOTOO, 2017). Over the years, plants subjected to this stress condition have developed adaptive responses, strategies extremely important in studies related to drought.

In plants, stress due to lack of water causes deleterious effects, such as reduced water potential, stomatal closure, oxidative damage, growth inhibition, and impaired productive capacity, with stomatal regulation as one of the first protective responses used by plants. The function of the stomata is to establish communication between the leaf mesophyll and the atmosphere, regulating the efflux of water and influx of $\mathrm{CO} 2$. Thus, in situations of stress, stomatal closure negatively influences the photosynthetic rate (FERRARI; PAZ; SILVA, 2015; HLAVÁČOVÁ et al., 2018; TAIZ et al., 2017).

The cowpea [Vigna unguiculata (L). Walp.] is one of the most cultivated crops in the North and Northeast regions of Brazil, with emphasis on the state of Ceará, which produced 109.9 thousand tons in the 2017/2018 harvest, generating an income of $\mathrm{R} \$ 300$ million (COMPANHIA NACIONAL DE ABASTECIMENTO, 2017). This culture has a wide range of genotypes. Among them, there are improved and traditional varieties, the latter represents great biodiversity in terms of genetic material and often having the preference of farmers (MANAF; ZAYED, 2015; RIVAS et al., 2016; SINGH; RAJA REDDY, 2011).
The investigation of this Creole genetic material allows to obtain different responses regarding the adaptive mechanisms to drought and can be used as parents in breeding programs. Given this scenario, we hypothesized that mapping the responses of traditional cowpea varieties is a strategy used to characterize mechanisms of adaptability or drought tolerance when subjected to severe stress, provided by prolonged drought events, followed by rehydration (resumed irrigation). Thus, the objective was to evaluate the physiological, morphological, and pod production characteristics of traditional cowpea varieties in drought tolerance and rehydration in the Brazilian semiarid region.

\section{MATERIAL AND METHODS}

\section{Experiment location}

The experiment was carried out in the city of Fortaleza, Ceará, Brazil, located in the coastal zone at $15.49 \mathrm{~m}$ altitude, $3^{\circ} 43^{\prime} 02$ "south latitude and $38^{\circ} 32^{\prime} 35^{\prime}$ " west longitude, in a greenhouse covered with plastic of 200 UV microns from the Phytotechnics Department, at Campus do Pici, at the Federal University of Ceará (UFC). The local climate is Aw', characterized by being tropical rainy according to the Köppen classification.

\section{Plant material and experimental conditions}

We used three cowpea genotypes, with two traditional varieties, the genotypes Sempre Verde (SV) and Feita de Moita (FM), which showed characteristics of tolerance to water deficit at seedling level, and a standard genotype for tolerance to drought (Pingo de Ouro 1,2; PO) (RIVAS et al., 2016). Table 1 shows some characteristics of the evaluated genotypes. The seeds were sown in Polyvinyl chloride (PVC) columns $(0.15 \mathrm{~m}$ in diameter and $0.5 \mathrm{~m}$ in height $)$, filled with medium texture soil, and fertilized according to the nutritional recommendation for the species, based on chemical analysis soil (Table 2). Thinning was carried out seven days after sowing (DAS), with one plant per column.

Table 1 - Cycle, type of size, length of the pod, number of seeds per pod, seed color, and weight of 100 seeds of the cowpea genotypes evaluated

\begin{tabular}{lccccc}
\hline Genotype & Type of size & Pod length $(\mathrm{cm})$ & $\mathrm{N}^{\circ}$ of seeds per pod & Seed color & W100s $(\mathrm{g})$ \\
\hline Sempre Verde & $\mathrm{Spr}$ & 16.6 & 13 & Greenish & 12.7 \\
Feijão de Moita & $\mathrm{Spr}$ & 20.5 & 15 & Cream & 18.7 \\
Pingo-de-Ouro-1,2* & $\mathrm{Spr}$ & 18.9 & 16 & Cream & 19.0 \\
\hline
\end{tabular}

*Bloodline in the final stage of recommendation. Spr: Semi-prostrate 
Table 2 - Soil fertility analysis

\begin{tabular}{|c|c|c|c|c|c|c|c|c|c|c|c|c|c|c|}
\hline \multirow{2}{*}{$\mathrm{C} \mathrm{g} \mathrm{kg}^{-1}$} & \multirow{2}{*}{ O.M } & \multirow{2}{*}{$\mathrm{pH}$} & $\mathrm{P}$ & $\mathrm{K}$ & $\mathrm{Ca}$ & $\mathrm{Mg}$ & $\mathrm{Na}$ & $\mathrm{Al}$ & $\mathrm{H}+\mathrm{AL}$ & $\mathrm{BS}$ & CEC & $\mathrm{V}$ & PES & $\mathrm{CE}$ \\
\hline & & & $\mathrm{mg} \mathrm{dm}{ }^{3}$ & & & & $\mathrm{mr}$ & $\mathrm{dm}^{3}$ & . & & ------- & \multicolumn{2}{|c|}{---- \% ----- } & $\mathrm{dS} \mathrm{m}^{-1}$ \\
\hline 7.39 & 12.75 & 6.6 & 102 & 1.24 & 20.7 & 6.6 & 0.33 & ND & 8.3 & 28.8 & 37.1 & 78 & 1 & 0.35 \\
\hline
\end{tabular}

O.M - Organic Matter; BS - Base Saturation; CEC - Cation Exchange Capacity; PES - Percentage of Exchangeable Sodium

Field capacity (FC) was determined, as described by Souza et al. (2000), considering the difference between the weight of wet soil after saturation and free drainage, and the weight of air-dried soil. The maintenance of FC was performed daily in all columns, by gravimetry, weighing them, and replacing the volume of water lost by evapotranspiration, using a scale with a capacity of $20 \mathrm{~kg}$ until the imposition of the deficit in the stress treatments.

The treatments with water deficit were imposed at 29 days after sowing (DAS), pre-flowering period, and phase of greatest water demand. This imposition was carried out through the suspension of irrigation. The following irrigation management conditions were applied: irrigated control (maintained at $80 \%$ of $\mathrm{FC}$ throughout the cycle) and progressive water deficit until it reaches a severe deficit (approximately 9 days of deficit, according to Rivas et al. (2016)). After reaching the severe deficit, irrigation was resumed for 4 days, to assess whether the genotypes would recover after the water deficit.

\section{Growth analytics}

The growth variables were evaluated: height of the aerial part (HAP), using a graduated ruler and measuring from the neck until the last leaf insertion, the number of leaves (NL), from the count of each fully expanded leaf, and finally, the stem diameter (SD) measured at $3 \mathrm{~cm}$ from the neck of the plant through a digital caliper. The evaluations started on the 1st day after the imposition of water stress, and continued every two days, until reaching the maximum stress (9 days). After the resumption of irrigation, another evaluation was carried out. For morphological characteristics, only one evaluation was carried out after the resumption of irrigation.

\section{Physiological analyzes}

The analysis of the photosynthetic parameters was carried out from 08:00 to 11:00 in the third completely expanded trefoil using an infrared gas analyzer (IRGA, Li-Cor - Li6400XT) with $\mathrm{CO}_{2}$

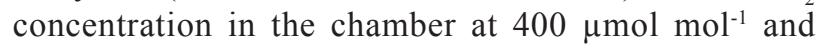
$1500 \mu \mathrm{mol}$ photons $\mathrm{m}^{-2} \mathrm{~s}^{-1}$. The liquid photosynthetic rate $\left(A, \mu \mathrm{mol} \mathrm{CO} 2 \mathrm{~m}^{-2} \mathrm{~s}^{-1}\right)$, stomatal conductance $(g s$, mol $\left.\mathrm{H}_{2} \mathrm{O} \mathrm{m}^{-2} \mathrm{~s}^{-1}\right)$, internal $\mathrm{CO}_{2}$ concentration $\left(\mathrm{C}_{\mathrm{i}}, \mu \mathrm{mol}\right.$ $\left.\mathrm{CO}_{2} \mathrm{~mol}^{-1}\right)$ and transpiration $\left(E, \mathrm{mmol} \mathrm{m}^{-2} \mathrm{~s}^{-1}\right)$. From the $A / E$ and $A / \mathrm{C}_{\mathrm{i}}$ ratios, Water Use Efficiency (WUE) and instant Carboxylation Efficiency (ICE) were calculated, respectively.

The fluorescence of chlorophyll a was analyzed using a fluorometer coupled to the IRGA (6400-40, LI-COR, USA) on the same sheet in which the gas exchanges were evaluated. For this purpose, the dark ones were acclimatized for 30 minutes. After the analysis, the potential photochemical efficiency of photosystem II (PSII) was calculated, expressed by the Fv/Fm ratio. With the fluorescence parameters collected in the clear (at the same time as the gas exchange determination), we determined the effective quantum yield of the FSII ( $\phi$ FSII), electron transport rate (ETR), and the non-photochemical extinction coefficient (NPQ).

The relative chlorophyll index (RCI) was determined using a SPAD chlorophyll meter (Soil Plant Analysis Development). Readings were taken between 9:00 am and 12:00 pm, on fully expanded sheets.

\section{Pods production}

For the characterization of the pods, we evaluated at the end of the experiment (55 DAS) in control and rehydrated plants: pod length (PL), number of pods per plant (NPP), number of seeds per pod (NSP), and weight of 100 seeds $\left(\mathrm{W}_{100 \mathrm{~s}}\right)$.

\section{Experimental design and statistical analysis}

The experimental design used was completely randomized, in a $3 \times 2$ factorial scheme (3 genotypes $\times 2$ soil water conditions) with 5 replicates for each treatment, totaling 30 experimental units. The data were subjected to analysis of variance (ANOVA) and, when significant, the means were compared by the Tukey test at the level of 5\% of significance. The programs used for statistical analysis and graph making were SAS [version 9.3 for Windows (SAS Institute, Inc., Cary, NC, USA, 2010)] and Sigmaplot [version 11.0 (SYSTAT Software, inc.)], respectively.

\section{RESULT AND DISCUSSION}

Effect of progressive water stress on growth and SPAD index 
The cowpea genotypes showed different behavior $(\mathrm{P}<0.05)$ by the Tukey test in all evaluated growth characteristics, which indicates the existence of variability between the different genotypes studied under these conditions. For the length of the aerial part (Figure 1A), there was a significant effect of water stress from the fifth day of deficit, with the FM genotype being the only one affected, with a reduction in the growth rate. At maximum stress (9 days), the irrigated PO and SV genotypes showed significant differences for the length of the aerial part, when compared with treatments under deficit. At the end of the rehydration period (13 days), there was no recovery of the aerial part of the genotypes grown under water stress.

For the stem diameter (Figure 1B), we observed significant differences only at the end of rehydration, where $\mathrm{SV}$ and PO differed from their controls. For the number of leaves (Figure 1C), we observed differences between treatments at maximum water stress and after rehydration. For the SPAD index (Figure 1D), we observed significant differences between treatments at the end of rehydration, with the irrigated PO genotype showing the highest mean and the FM under stress with the lowest mean. This index is important, since chlorophyll contents are directly related to photosynthetic rates and, consequently, affect plant growth.

Water is considered the main environmental factor for regulating the growth and development of a plant. Thus, the ability to resist or tolerate the lack of water is of fundamental importance for the continuity of its life cycle (SHAO et al., 2008). We observed greater sensitivity of the genotypes to drought, mainly for the length of the aerial part and number of leaves (Figures 1A and 1C, respectively), while the $\mathrm{SD}$ (Figure $1 \mathrm{~B}$ ) showed variations throughout the experiment, with a noticeable decrease at maximum stress. On the other hand, the SPAD index decreased with the intensification of the water deficit, a reduction, caused by greater degradation or lesser synthesis of photosynthetic pigments.

When grown under water restriction conditions, the plants may have impaired growth, development, and production due to the low availability of water (NOBRE et al., 2013). The authors also mentioned that the

Figure 1 - Effects of progressive water stress and rehydration on Shoot length (cm; A), SD - Stem diameter (mm; B); NL - Number of leaves (C); Relative chlorophyll index (SPAD; D) in three cowpea genotypes: Pingo de Ouro 1,2 (PO; circles), Sempre Verde (SV; triangles) and Feijão de Moita (FM; squares). Black markings mean control treatments, while white markings refer to water stress. From 9 - 13 days represents the rehydration phase. Values are means ( \pm Standard Error) for five plants

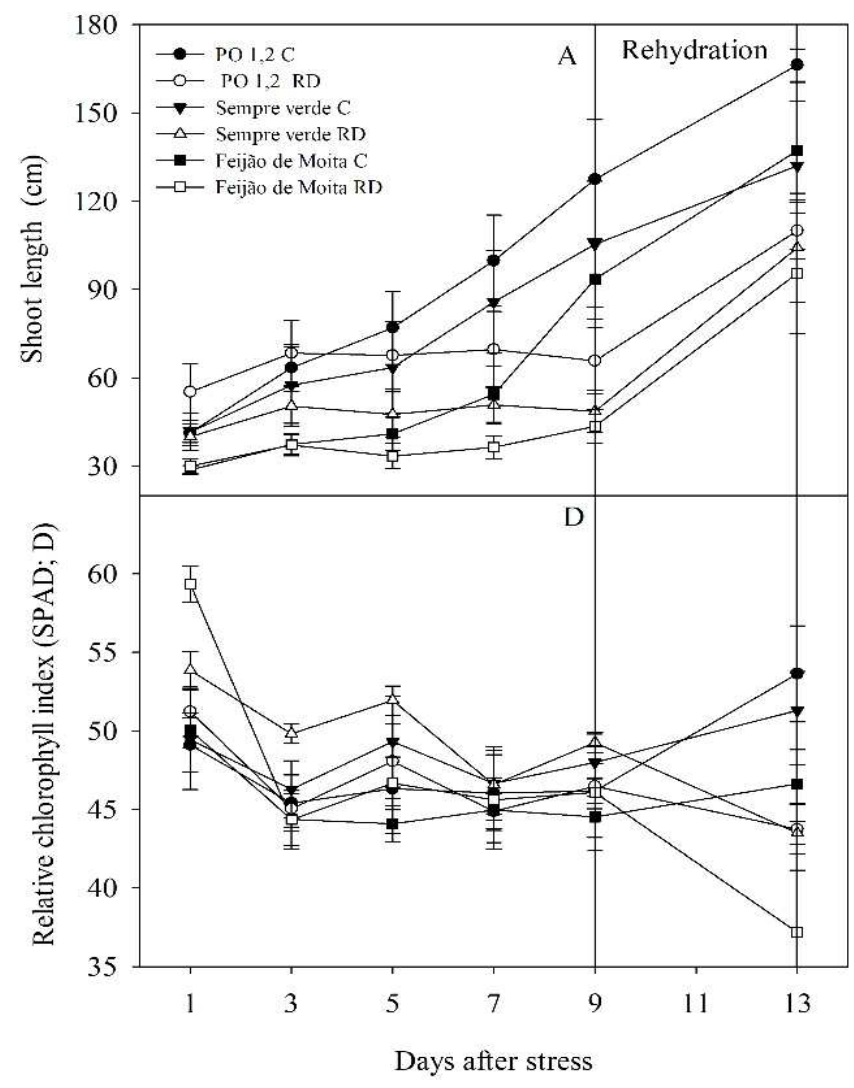

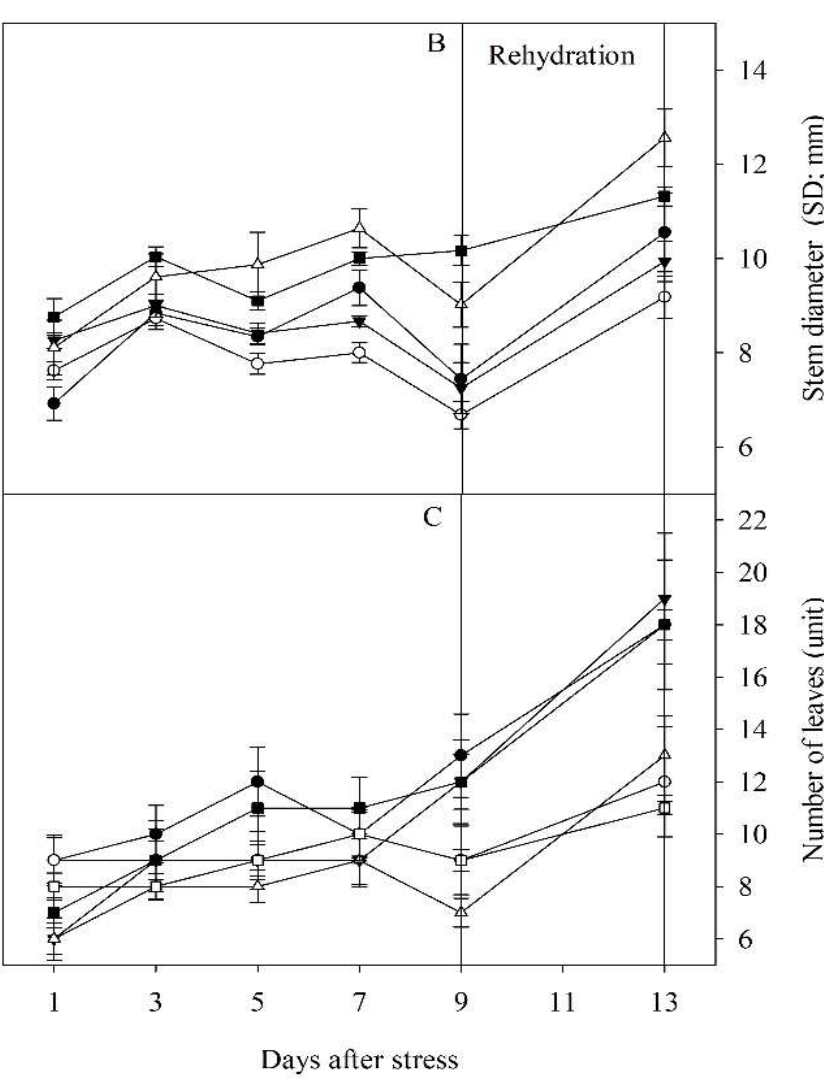

Days after stress 
reduction in the water potential of tissues causes growth restriction since the rates of elongation and cell division to depend directly on the extensibility process of the cell wall (SOUSA et al., 2011). The data mainly on shoot length and number of leaves demonstrated this type of response. Regarding the SPAD index, it is important for the determination of chlorophyll contents, as it is a noninvasive and fast method and also because chlorophyll contents are directly related to photosynthetic rates and, consequently, affect plant growth.

\section{Effect of water stress and rehydration on photosynthetic parameters}

Liquid photosynthesis $(A)$ (Figure 2A) showed a reduction for the three genotypes under the condition of progressive drought. On the third day, the reduction was $58.9,60.0$, and $56.9 \%$ for the PO, SV, and FM genotypes, respectively. The minimum value was verified at the maximum stress (nine days of water suspension), in which there was no significant difference between the genotypes. The resumption of irrigation favored the recovery of A, and after four days of rehydration, recovery at a control level was observed in all genotypes.

The responses of stomatal conductance $(g s)$ (Figure 2B) and transpiration (E) (Figure 2C) were

Figure 2 - Effects of progressive water stress and rehydration on the photosynthetic parameters of three cowpea genotypes: Pingo de Ouro 1.2 (circles), Sempre Verde (triangles), and Feijao de Moita (squares). Black markings mean control treatment, while white markings refer to water stress. From 9 - 13 days represents the rehydration phase. Values are means ( \pm Standard Error) for five plants
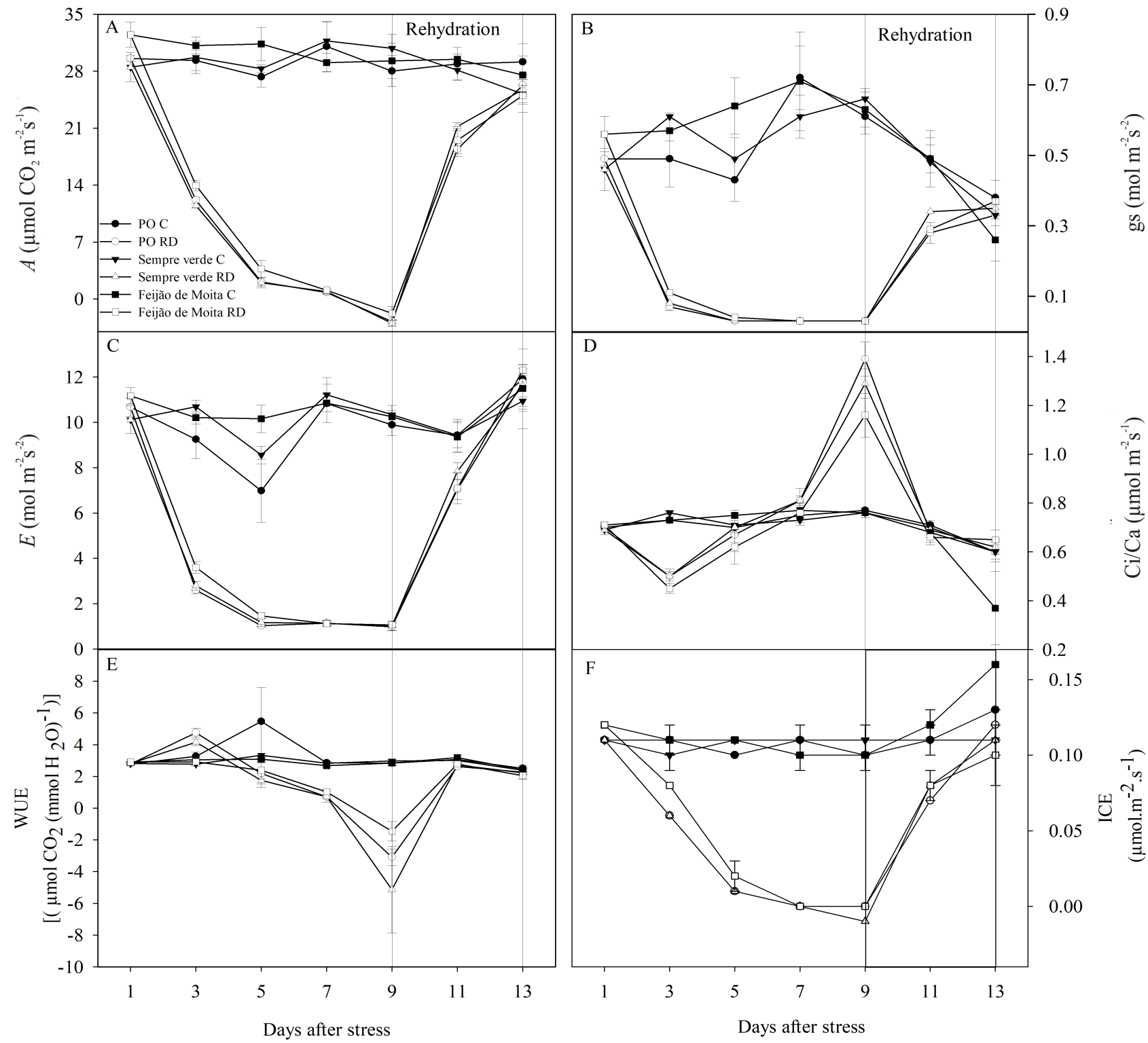
similar to those of A, however, with an almost immediate decrease after the imposition of water stress. For $g s$, reductions in stomatal opening up to maximum stress were 93.88, 93.47, and 94.64\% for the PO, SV, and FM genotypes, respectively; while for $\mathrm{E}$, the reductions for the three genotypes were on average $90 \%$. After rehydration, recovery was only observed on the fourth day of irrigation, demonstrating that there may be a recovery in these variables if irrigation resumes or rainfall occurs.

For the $\mathrm{Ci} / \mathrm{Ca}$ ratio (Figure 2D), a reduction was initially observed due to the closure of stomata and a reduction in the $\mathrm{CO}_{2}$ inflow. However, the intensification of water stress caused an increase in this ratio, possibly due to increased breathing and accumulation of $\mathrm{CO}_{2}$. At the end of the water stress, the values of plants under deficit were higher than their controls. There was no statistical difference between the genotypes within each water condition. In the first assessment after rehydration, we observed recovery at the control level.

The instant efficiency of water use (Figure 2E) varied according to the exposure to stress. There was a significant reduction up to the maximum water stress (nine days), where the SV genotype differed from the other genotypes. The reduction in these rates, up to the maximum stress, was $165.0,223.5$, and $150.0 \%$ for the PO, SV, and FM genotypes, respectively. After rehydration, the plants were restored to a control level in the first evaluation carried out with two days.

The instant efficiency of carboxylation (Figure 2F) decreased progressively, with the lowest averages being verified at maximum stress, with an average reduction of $90 \%$ for all genotypes under water deficit. After rehydration, we observed a recovery over the four days, and at the end of this phase, there were no significant differences between treatments, or between genotypes.

As one of the main responses when studying the behavior of plants in unfavorable environments, the gas exchange has been widely used to detect the effects of stress on the functioning of the photosynthetic system (LIU et al., 2019). These determinations allow us to characterize the extent of changes in stomatal control in response to water deficit and its consequences on the photosynthetic metabolism of the leaf. During water stress, damage to photosynthetic machinery occurs mainly from the restriction of stomatal opening, governed by low water availability in the soil (HLAVÁČOVÁ et al., 2018; TOMBESI et al., 2018). As a result, the plant avoids the loss of water by stomata. On the other hand, production restriction occurs due to the limitation in $\mathrm{CO}_{2}$ fixation, inhibiting its growth and development (RIVAS et al., 2016).

In this study, a progressive decrease in the rates of $A, E, g s$, and EiC was observed (Figure 2) with the intensification of stress in all genotypes, other authors also reported similar responses (MUNJONJI et al., 2018; SINGH; REDDY, 2011). However, according to the results obtained, there seems to be a rapid recovery after the resumption of irrigation. These results corroborate with the study on responses of cowpea genotypes to drought and rehydration, prepared by Rivas et al. (2016), in which the authors showed that the intensification of water stress reduced the rates of liquid photosynthesis and stomatal conductance, showing their reestablishment after rehydration.

$E$ and $A$ responses are directly related to stomatal closure induced by the imposition of water stress, as a measure used to reduce the loss of water to the atmosphere (DUTRA et al., 2015; NAIDOO; NAIDOO, 2018). The three genotypes were shown to be efficient in this stomatal regulation and reduction in $\mathrm{E}$ rates, as a mechanism to reduce water loss (BHUSAL; HAN; YOON, 2019). As for the efficiency of water use (Figure 1E), we observed positive responses up to the fifth day of water restriction for the three genotypes, revealing that this regulation of the WUE can be effective for tolerating moderate stress (five days). For this variable, the FM genotype showed significantly lower averages in maximum stress, indicating that the prolongation of the deficit would make it more susceptible concerning the others. The work carried out by Carvalho et al. (2019), corroborated with the data of this research and further suggests that, the greater efficiency in the regulation of the WUE can characterize tolerant genotypes.

The $\mathrm{Ci} / \mathrm{Ca}$ ratio (Figure 2D) varied throughout exposure to drought, with averages decreasing in the first days in all genotypes, probably due to the low $\mathrm{CO}_{2}$ influx that occurred as a result of stomatal closure. After this period, there was a continuous increase in this ratio up to nine days, for plants under stress. As the ambient $\mathrm{CO}_{2}$ content is constant, this increase suggests that there is an accumulation of $\mathrm{CO}_{2}$ inside the leaf mesophyll, probably, this accumulation is occurring due to biochemical limitations in enzymes involved in the fixation of $\mathrm{CO}_{2}$, which prevent the plant from assimilating it (GUERRA et al., 2014; TATAGIBA et al., 2014).

The instant efficiency of carboxylation (Figure 2F) is a variable that has a close relationship with the internal concentration of $\mathrm{CO}_{2}$ and its assimilation rate and it depends on the activity of enzymes that regulate photosynthesis (DUTRA et al., 2015; SILVA et al., 2015). In this study, the averages were decreasing after the imposition of the deficit. These data suggest that the $\mathrm{CO}_{2}$ assimilation mechanism may be compromised, favoring the accumulation of carbon and negatively influencing photosynthetic rates, contributing to a decrease in EiC, in other words, the increase in this variable suggests stomatal limitations and non-stomatal (SILVA et al., 2016). 
Therefore, the recovery of gas exchange rates after rehydration indicates that water stress did not permanently affect machinery and photosynthetic activity (SOUZA et al., 2004) and that the resumption of irrigation after stress is essential for the survival of plants, leading to the acceptance of the hypothesis that the maintenance of irrigation after a deficit period is a strategy to characterize mechanisms of adaptability or drought tolerance.

Effect of water stress and rehydration on the fluorescence parameters of chlorophyll a

The potential quantum efficiency of PSII (Figure 3A) did not differ between treatments or between genotypes, with values ranging from 0.78 to 0.85 over the evaluation period and with PO control was superior to the others, on the first day. In general, the tolerant genotype had the highest averages in the irrigated treatment. After the reestablishment of irrigation, the averages had a slight increase after four days.

The effective quantum yield of the FSII (Figure 3C) decreased with the intensification of the water deficit. At the end of rehydration, this variable recovered in the treatment plants due to drought. Figure $3 \mathrm{~F}$ shows the effects of progressive water stress on the electron transport rate (ETR), observing a declining trend, and the effects of water deficit caused an average reduction of around $80 \%$ in all. After rehydration, we observed that both variables showed positive responses and that after four days there was recovery at the level of control treatment.

For the NPQ (Figure 3E) there were increases in the averages in response to the water deficit, while the control treatment showed small variations. Therefore, we observed that the treatment with water restriction increased the averages in the following proportions: $166.70 \%$ for the PO genotype, $149.37 \%$ for the SV, and $181.65 \%$ for the FM.

\section{Effect of water stress on production characters}

The analysis of variance reveals that the genotype factor was significant for pod length, number of pods per plant, and weight of 100 seeds (Table 3 ). The water condition was significant for PL, NSP, and W100s, while we observed significant interaction only for NPP and W100s.

Figure 3 - Effects of progressive water stress and rehydration on the chlorophyll fluorescence parameters of three cowpea genotypes: Pingo de Ouro 1.2 (circles), Sempre Verde (triangles), and Feijão de Moita (squares). Black markings mean control treatment, while white markings refer to water stress. From 9 - 13 days represents the rehydration phase. Values are means ( \pm Standard Error) for five plants
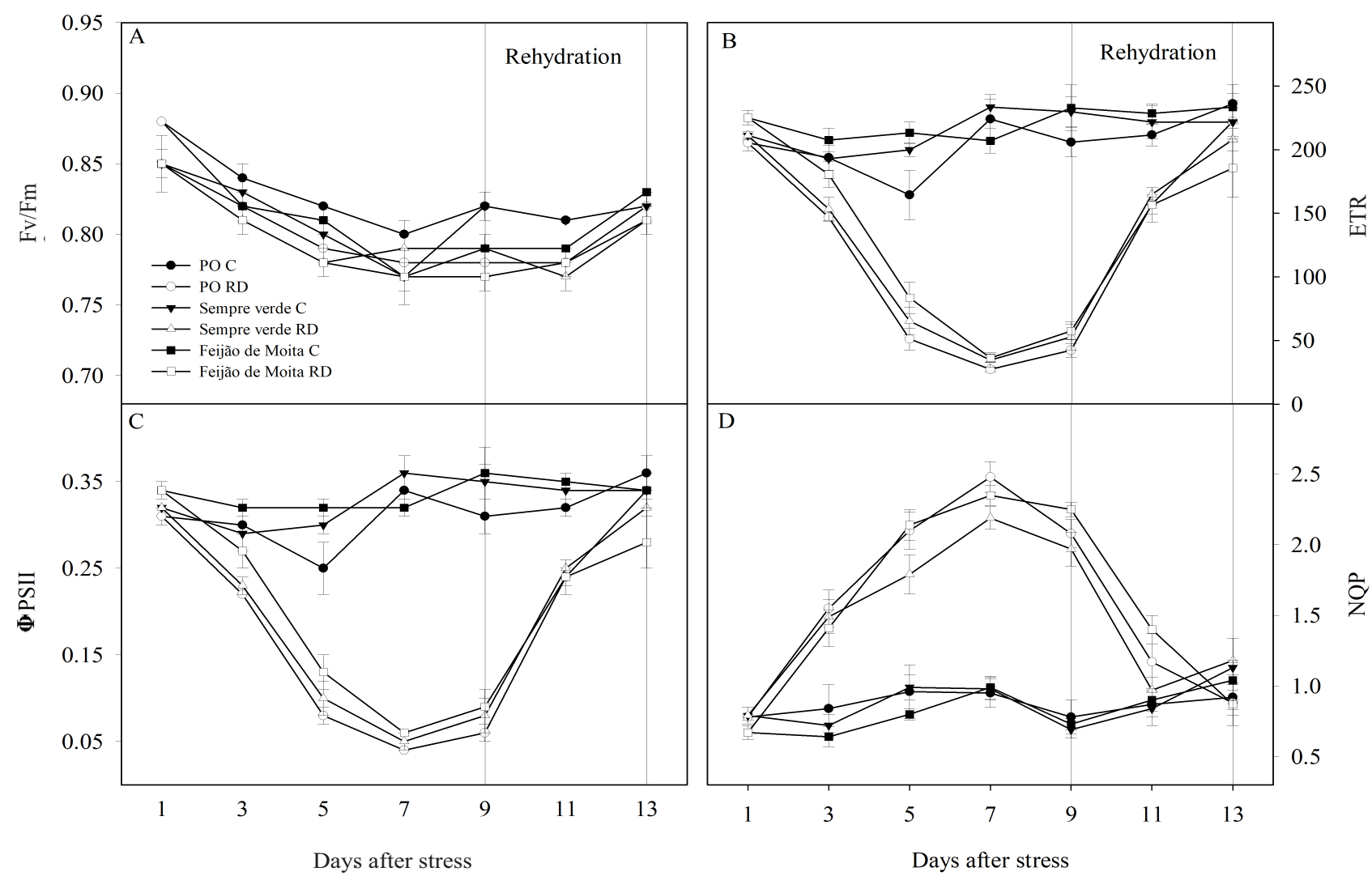
For the PL (Table 4), we observed that the plants were affected by the imposition of the water deficit, presenting a reduction of $11.84 \%$. The creole genotypes do not differ from the tolerant genotype, for this variable. For the Number of Pods per Plant (NPP), all genotypes differed between treatments, with emphasis on the PO genotype, which presented means higher than the control treatment, with an increase in this variable of $53.33 \%$. On the other hand, the other genotypes showed a reduction of around $50 \%$ in the NPP. Among the genotypes, the highlight was the PO genotype, which differed from the others when subjected to water stress and rehydration.

The NSP did not show significant interaction, only the effect of the imposed water condition, in which a reduction of $9.16 \%$ was noted when comparing the group of plants in a control situation with the group under water deficit. The W100s differed between treatments, only among Creole genotypes, with reductions of around $25 \%$ for both. Among the genotypes, the PO showed significantly higher averages after water stress, concerning the Creole genotypes.
Comparing the genotypes under water deficit, we observed that the PO has characteristics that confirm its tolerance potential since for NPP and W100s they presented means superior to the other genotypes. The characteristics NPP, NSP, and W100s are strongly related to grain yield so that a water stress tolerant genotype must have high values of secondary production components (SILVA et al., 2016). The leaf area can be directly related to production, considering that the leaves are a source of photoassimilates for the development of roots and that these are structures that participate in the assimilation of nutrients and play an important role in resisting water deficit (BONFIM SILVA et al., 2011). Therefore, the fact that the Creole genotypes under stress had lower leaf numbers and NPP than the control treatment corroborates the hypothesis that the production depends on a larger leaf area. However, the Creole genotypes did not differ from the standard tolerance genotype in the variables of pod length and number of seeds per pod, demonstrating a stress response, and satisfactorily maintaining some production characters.

Table 3 - Summary of the analysis of variance for the variables pod length (PL), number of pods produced (NPP), number of seeds per pod (NSP), and weight of 100 seeds ( W100s ) in cowpea plants, submitted to water deficit

\begin{tabular}{lcccc}
\hline \multirow{2}{*}{ Sources of variation } & \multicolumn{4}{c}{ Mean Square } \\
\cline { 2 - 5 } & PL $(\mathrm{cm})$ & NPP (und) & NSP (und) & W100s $(\mathrm{g})$ \\
\hline Genotype (G) & $7.26^{*}$ & $24.0^{*}$ & $1.5^{\text {ns }}$ & $47.5^{*}$ \\
Water condition $(\mathrm{WC})$ & $36.08^{*}$ & $4.16^{\mathrm{ns}}$ & $12.0^{*}$ & $113.2^{*}$ \\
G x WC & $2.17^{\mathrm{ns}}$ & $28.16^{*}$ & $2.6^{\mathrm{ns}}$ & $53.34^{*}$ \\
Residue & 0.04 & 2.22 & 2.33 & 2.96 \\
\hline CV $(\%)$ & 7.17 & 25.93 & 12.64 & 8.72 \\
\hline
\end{tabular}

*Significant by the $\mathrm{F}$ test at 0.05 ; ns - not significant

Table 4 - Effect of water stress on productive traits in different cowpea genotypes: Pingo de Ouro 1,2 (PO), Sempre Verde (SV), and Feijão de Moita (FM). Values represent the mean ( \pm Standard Error) for five plants

\begin{tabular}{lcccccccc}
\hline \multirow{2}{*}{ Genotypes } & \multicolumn{2}{c}{ Pods Length } & \multicolumn{2}{c}{ NPP (und) } & \multicolumn{2}{c}{ NSP(und) } & \multicolumn{2}{c}{ W100s (g) } \\
\cline { 2 - 8 } & Control & WD & Control & WD & Control & WD & Control & WD \\
\hline PO & $20.6 \mathrm{aA}$ & $16.9 \mathrm{aA}$ & $6.0 \mathrm{aB}$ & $9.5 \mathrm{aA}$ & $13.0 \mathrm{aA}$ & $10.2 \mathrm{aA}$ & $23.8 \mathrm{aA}$ & $21.2 \mathrm{aA}$ \\
SV & $21.4 \mathrm{aA}$ & $19.5 \mathrm{aA}$ & $6.3 \mathrm{aA}$ & $3.2 \mathrm{bB}$ & $12.7 \mathrm{aA}$ & $11.9 \mathrm{aA}$ & $20.1 \mathrm{aA}$ & $15.7 \mathrm{bB}$ \\
FM & $21.4 \mathrm{aA}$ & $19.7 \mathrm{aA}$ & $6.2 \mathrm{aA}$ & $3.3 \mathrm{bB}$ & $12.7 \mathrm{aA}$ & $11.8 \mathrm{aA}$ & $20.9 \mathrm{aA}$ & $14.7 \mathrm{bB}$ \\
Average & $21.1 \mathrm{~A}$ & $18.6 \mathrm{~B}$ & $6.1 \mathrm{~A}$ & $5.3 \mathrm{~A}$ & $13.1 \mathrm{~A}$ & $11.9 \mathrm{~B}$ & $21.6 \mathrm{~A}$ & $17.2 \mathrm{~B}$ \\
\hline
\end{tabular}

PL - Pods Length; NPP - Number of pods per plant; NSP - Number of seeds per pod; W100s - Weight of one hundred seeds. Means followed by the same lower-case letters (between genotypes), and upper-case letters (comparison between water conditions), do not differ by the Tukey test, at $5 \%$ probability 


\section{CONCLUSIONS}

1. The characterization of genotypes versus water deficit showed that drought negatively affected cowpea genotypes, especially in traditional genotypes, which had negative effects on the morphological level and pod production, with the genotype Feijão de Moita being the most sensitive to the deficit;

2. Regarding the physiological characters, the Creole genotypes showed characteristics of gas exchange and chlorophyll fluorescence similar to the standard tolerance genotype, Pingo de Ouro 1,2;

3. For the characteristics of pods, the genotype Pingo de Ouro 1,2, in general, showed better responses under the condition of stress. However, the Creole genotypes responded to water stress maintaining the length of the pods and the number of seeds per pod.

\section{ACKNOWLEDGMENTS}

To Fundação Cearense de Apoio ao Desenvolvimento Científico e Tecnológico (FUNCAP), and the Programa de Pós-Graduação em Agronomia/ Fitotecnia (PPGAF), for the financial support to carry out this study and to the group of Estudos em Ecofisiologia da Produção e Nutrição de Plantas (GEEPEN), belonging to Universidade Federal do Ceará (UFC).

\section{REFERENCES}

BHUSAL, N.; HAN, S.; YOON, T. Impact of drought stress on photosynthetic response, leaf water potential, and stem sap flow in two cultivars of bi-leader apple trees (Malus x domestica Borkh.). Scientia Horticulturae, v. 246, n. November 2018, p. $535-543,2019$.

BONFIM-SILVA, E. M. et al. Desenvolvimento inicial de gramíneas submetidas ao estresse hídrico. Revista Caatinga, v. 24, n. 2, p. 180-186, 2011.

CARDOSO, M. J.; MELO, F. D. E. B.; RIBEIRO, V. Q. Population density on cowpea cultivars with different growth habits in the matopiba region 1. Revista Caatinga, v. 2125, p. 235-239, 2018.

CARVALHO, M. et al. Evaluating stress responses in cowpea under drought stress. Journal of Plant Physiology, v. 241, 2019.

CHEN, Z. et al. Abscisic acid and brassinolide combined application synergistically enhances drought tolerance and photosynthesis of tall fescue under water stress. Scientia Horticulturae, v. 228, n. August 2017, p. 1-9, 2018.

COMPANHIA NACIONAL DE ABASTECIMENTO (BRASIL). Acompanhamento de safra brasileira: grãos: terceiro levantamento. Brasília, DF: Conab, dez. 2017.
DUTRA, F. et al. Parâmetros fisiológicos e componentes de produção de feijão-caupi cultivado sob deficiência hídrica. Revista Brasileira de Ciências Agrárias, v. 10, n. 2, p. 189-197, 2015.

FERRARI, E.; PAZ, A. da; SILVA, A. C. da. Déficit hídrico no metabolismo da soja em semeaduras antecipadas no Mato Grosso. Nativa - Pesquisas Agrárias e Ambientais, v. 3, n. 2, p. $67-77,2015$.

GUERRA, A. M. N. et al. Capacidade fotossintética de plantas de algodoeiro infectadas por ramulose e supridas com silício. Bragantia, v. 73, n. 1, p. 50-64, 2014.

HLAVÁČOVÁ, M. et al. Interactive effects of high temperature and drought stress during stem elongation, anthesis and early grain filling on the yield formation and photosynthesis of winter wheat. Field Crops Research, v. 221, n. February, p. 182-195, 2018.

IHUOMA, S. O.; MADRAMOOTOO, C. A. Recent advances in crop water stress detection. Computers and Electronics in Agriculture, v. 141, p. 267-275, 2017.

LI, J. et al. Influence of drought stress on photosynthetic characteristics and protective enzymes of potato at seedling stage. Journal of the Saudi Society of Agricultural Sciences, v. 16, n. 1, p. 82-88, 2017.

LIU, B. et al. Drought stress affects on growth, water use efficiency, gas exchange and chlorophyll fluorescence of Juglans rootstocks. Scientia Horticulturae, v. 250, n. November 2018, p. 230-235, 2019.

MANAF, H. H.; ZAYED, M. S. Productivity of cowpea as affected by salt stress in presence of endomycorrhizae and Pseudomonas fluorescens. Annals of Agricultural Sciences, v. 60, n. 2, p. 219-226, 2015.

MUNJONJI, L. et al. Stomatal behavior of cowpea genotypes grown under varying moisture levels. Sustainability, v. 10, n. 12, p. 1-16, 2018.

NAIDOO, G.; NAIDOO, K. K. Drought stress effects on gas exchange and water relations of the invasive weed Chromolaena odorata. Flora, v. 248, n. August, p. 1-9, 2018.

NOBRE, R. G. et al. Emergência, crescimento e produção da mamoneira sob estresse salino. Revista Ciência Agronômica, v. 44, n. 1, p. 76-85, 2013.

PAIVA, J. B. et al. Feijão-caupi: melhoramento genético no Centro de Ciências Agrárias. Fortaleza: Edições UFC, 2014. 261 p.

RIVAS, R. et al. Drought tolerance in cowpea species is driven by less sensitivity of leaf gas exchange to water deficit and rapid recovery of photosynthesis after rehydration. South African Journal of Botany, v. 103, p. 101-107, 2016.

SHAO, H. et al. Water-deficit stress-induced anatomical changes in higher plants. Plant Biology and Pathology, v. 331, p. $215-225,2008$.

SILVA, F. G. et al. Trocas gasosas e fluorescência da clorofila em plantas de berinjela sob lâminas de irrigação. Revista Brasileira de Engenharia Agrícola e Ambiental, v. 19, n. 10, p. 946-952, 2015. 
SILVA, G. C. et al. Rendimento de grãos secos e componentes de produção de genótipos de feijão-caupi em cultivo irrigado e de sequeiro. Revista Agro@Mbiente on-Line, v. 10, n. 4, p. 342, 2016.

SILVA, R. G. G. et al. Drought increases cowpea (Vigna unguiculata [L.] Walp.) susceptibility to cowpea severe mosaic virus (CPSMV) at early stage of infection. Plant Physiology et Biochemistry, v. 109, p. 91-102, 2016.

SINGH, S. K.; RAJA REDDY, K. Regulation of photosynthesis, fluorescence, stomatal conductance and water-use efficiency of cowpea (Vigna unguiculata [L.] Walp.) under drought. Journal of Photochemistry and Photobiology B: Biology, v. 105, n. 1, p. 40-50, 2011.

SINGH, S. K.; REDDY, K. R. Regulation of photosynthesis, fluorescence, stomatal conductance and water-use efficiency of cowpea (Vigna unguiculata [ L .] Walp.) under drought. Journal of Photochemistry \& Photobiology, B: Biology, v. 105, n. 1, p. 40-50, 2011.

SOUSA, A. E. C. et al. Crescimento e consumo hídrico de pinhão manso sob estresse salino e doses de fósforo. Revista Ciência Agronômica, v. 42, n. 2, p. 310-318, 2011.
SOUZA, C. C. et al. Avaliação de métodos de determinação de água disponível e manejo da irrigação em terra roxa sob cultivo de algodoeiro herbáceo. Revista Brasileira de Engenharia Agrícola e Ambiental, v. 4, n. 3, p. 338-342, 2000 .

SOUZA, R. P. et al. Photosynthetic gas exchange, chlorophyll fluorescence and some associated metabolic changes in cowpea (Vigna unguiculata) during water stress and recovery. Environmental and Experimental Botany, v. 51, p. 45-56, 2004.

TAIZ, L. et al. Fisiologia e desenvolvimento vegetal. Porto Alegre: Artmed, v. 6 ed., p. 59-74, 2017.

TATAGIBA, S. D. et al. Limitações fotossintéticas em folhas de plantas de tomateiro submetidas a crescentes concentrações salinas. Engenharia na agricultura, v. 22, n. 2, p. 138-149, 2014.

TOMBESI, S. et al. Effect of water stress "memory" on plant behavior during subsequent drought stress. Environmental and Experimental Botany, v. 150, n. January, p. 106-114, 2018. 